\title{
Videoconferencing Imitating Television in Foreign Language Instruction
}

\author{
Timothy Cook \\ Iryo Sosei University
}

\begin{abstract}
This is a report on a videoconference conducted by a Japanese university seminar, the topic of which is language learning with online language exchange partners. The Japanese students are studying English and their partners are English speakers studying Japanese at American universities. While the technology used in the videoconference was limited to on-hand hardware and free software, it was staged as an interactive television show informed by the author's past experience in distance learning programming. The reactions to the videoconference, from seminar and remote students, are discussed and suggestions for further exploration are offered.

これは、日本の大学のゼミで行われた「オンラインによる言語交換パートナーとの言語 学習」をテーマにしたビデオ会議のレポートである。日本の大学生は英語を学んでお り、言語交換相手はアメリカの大学で日本語を学ぶ大学生たちだ。ビデオ会議に使用さ れた技術は、手持ちのハードウェアと無料のソフトというごく限られたものだったが、 筆者が過去に経験した遠隔教育番組の経験を生かし、インタラクティブなテレビ番組の ように演出がされている。日本のゼミ生や相手側の学生によるビデオ会議への反応を考 察し、さらなる調查のための提案が萀められる。
\end{abstract}

\section{Introduction}

This report is of a videoconference conducted by a Japanese university junior-senior seminar I teach concentrating on language learning through language exchange (also known as "tandem language exchange" and "telecollaboration") with remote partners online. Unlike typical instructional videoconferencing, which serves to recreate the teacher-student dynamic of the classroom, the design of this videoconference was as an interactive television show with the 
narrative elements of a variety show, a sit-com, and a call-in talk show. It required those on camera to take on a theatrical role while they teach Japanese.

In the 1990s, I developed this same design for teaching Japanese in a high school program for American public television entities. Beginning in the 1980s, such distance learning courses emerged via various transmission systems such as satellite and microwave frequencies. Writing in 2010, Carey and Elton recount that these "very simple interactive television services...reached thousands of primary, secondary, and university students, typically providing courses that would not otherwise have been available in rural areas or small school districts (e.g., advanced mathematics or foreign languages such as Russian or Japanese)” (p. 261). My particular television course enrolled over 1,000 high school students. Voice interaction with me, the TV instructor, was so infrequent for any one student as to have minimal impact on his or her Japanese fluency. Instead, I used student interaction as a kind of fishbowl for all the other students not interacting that day to learn through observation. Each lesson was embedded with humorous stories, to which the resolution required student interaction in the language being taught. Although contemporaneous studies did not focus on the theatricality I and my producer/director endeavored to incorporate into the course, they tended to view the instruction overall in a favorable light (peerreviewed studies limited to Bruning et al., 1993, and Yi \& Majima, 1993) and the course proved the most popular of all the courses that the interstate service offered. ${ }^{1}$

Digital video technology has made video production "accessible and affordable" and it "simplifies the production process" (Masats et al., 2009, p. 344). That which used to be limited to TV stations can now be accomplished with one's laptop and smartphone, even if production quality is not up to broadcast standards. I wanted to see if such a design could in any way be reproduced today without the professional broadcast apparatus or acting talent and coaching to which I once had access.

1 The course, produced by Nebraska Educational Telecommunications and the Nebraska Department of Education, was offered through the Satellite Educational Resources Consortium (SERC), a compact of 18 American states and their public broadcasting entities and departments of education, sharing each other's distance learning courses from the mid-1980s to the mid-2000s. Important for language learning purposes, a significant component of the design of the Japanese course was a bank of Japanese teaching assistants who spoke by telephone audiobridge with all students in groups of 10 for 20 minutes of class time twice a week. 
My original rationale for retaining common signifiers of broadcast entertainment in my television teaching was to acknowledge students' presumed expectations when they watch TV. People watch television not because they have to, but because they want to, and to the degree that was possible, I wanted to make students watch my instruction because they wanted to. My assumption was that if I could be successful in that pursuit, students would learn Japanese better. As the uses of video technology have broadened far beyond broadcast television since the 1990s, viewers of any video format have less fixed expectations of what they will see. Students participating in a class on a videoconferencing platform today would not expect it to be a TV show. However, I was curious what participants' reactions would be if it did feel like a familiar genre of entertainment television. At the end of the of the videoconference, after the "show" was finished and the seminar students were no longer in character, I asked remote students for their informal reactions in a group discussion. The following week, I had the seminar students talk about the experience in a class discussion.

\section{The Design}

\section{Seminar Design}

The seminar consists of five students of English, for whom I have facilitated communication with overseas partners. Some of the communication has been one-on-one and some class-to-class. Locating partners through various language exchange websites, online teacher discussion groups, and my personal contacts with instructors of Japanese abroad, we have experimented with various platforms for both synchronous and asynchronous exchanges. As is the practice in language exchanges, approximately half the time students speak in their native language and the other half in the language of their partners, usually at designated times.

The focus of the seminar has been on language exchange, not videoconferencing per se. While the students who joined the seminar were open to acting on camera, it was neither part of their experience nor their main motivation to enroll. Moreover, the seminar videoconferences lack any of the trappings of professional broadcast television. At best, I could only approximate such trappings with the limited video tools, production skills, and acting talent at my disposal. 


\section{Videoconference Design}

This videoconference connected my five seminar students with 12 students of Japanese in three universities in the United States. Because of both the time difference between Japan and the U.S., and the U.S. COVID-19 situation, students in the U.S. joined the videoconference from their respective homes. Live video and audio from all the participants were transmitted to each other via Zoom; however, the seminar students on the Japan side were focused on directly addressing the camera, or each other at the appropriate points, and did not look at the Zoom video.

In previous assignments, I had students try their hand at scriptwriting, but despite supplying them with interactive narrative examples and efforts to steer them away from composing pedantic lectures, my expectations turned out to be unrealistic. Students came up with scripts appropriate for an instructional setting, all with interesting information, but the scripts were mostly that: informative. For example, in a previous videoconference, after explaining what measures the Japanese students had taken for COVID-19, one student asked what measures American students had taken. The scripts had little sense of theatricality which I had attempted to foster. For the videoconference that is the focus of this paper, I wrote the basic script myself while incorporating students' ideas and suggestions. A representative section of the script is in Table 1. The script was printed in big letters on several sheets of paper, taped together, and scrolled by an off-camera student standing close to the cameras so that on-camera students could read it while appearing to look directly at the camera.

\section{Table 1}

A Segment of the Videoconference Script

\begin{tabular}{ll}
\hline Camera & Dialogue \\
\hline CAM 2: Student A & A: (sighs in frustration) Teacher, can I go \\
& to the bathroom?
\end{tabular}

CAM 1: Teacher

$\mathrm{T}$ : The bathroom? $\mathrm{S}$, this is a Japanese class now. Can he go to the bathroom? Is that OK? 
T: (react) Yes, (reluctantly) B, it's OK.

You can go to the bathroom.

CAM 2: Student B prances out of room A: Thank you.

T: But come back soon, OK?

A: Okaaay. (prances out of room)

Note. This is an English translation of the script, which was in Japanese. In previous lines, Student A asks twice if he can go to the bathroom, but the person playing the teacher role gets distracted talking to online students and fails to answer Student A's request. In the lines under CAM 1: Teacher, $\leq$ refers to a remote student whom the teacher calls. The 'I' in the middle of the script stands for interaction.

As the script segment shows, the seminar students' speaking is scripted out in advance; however, the online students' speaking, indicated by the capital "I," is not scripted. Their reactions are genuine as they grapple with the appropriate Japanese to meet the situation. At several points, the remote students either did not know how to respond or the seminar students were not able to make out what a remote student said. I, who was off camera, occasionally gestured responses for the on-camera students to make.

The videoconference was conducted entirely with on-hand equipment and free downloadable software. A laptop computer received video and audio wirelessly from the cameras and microphones built into smartphones through an app called Irium Webcam. On the laptop, OBS Studio, an open-source program for live and recorded video production, was used for switching between cameras and adding preproduced elements for the Zoom feed. OBS Studio was also used to mix the audio of the seminar students and the remote participants, and finally to record the entire 
production. $^{2}$ The OBS Studio user interface is shown in Figure 1. The image on the right is what is sent out to the program, in this case Zoom. The image on the left is the next scene cued up to be shown after the user transitions to it.

\section{Figure 1}

Screenshot of OBS Studio Software with a Graphic and Katherine Maher During Wikipedia 20

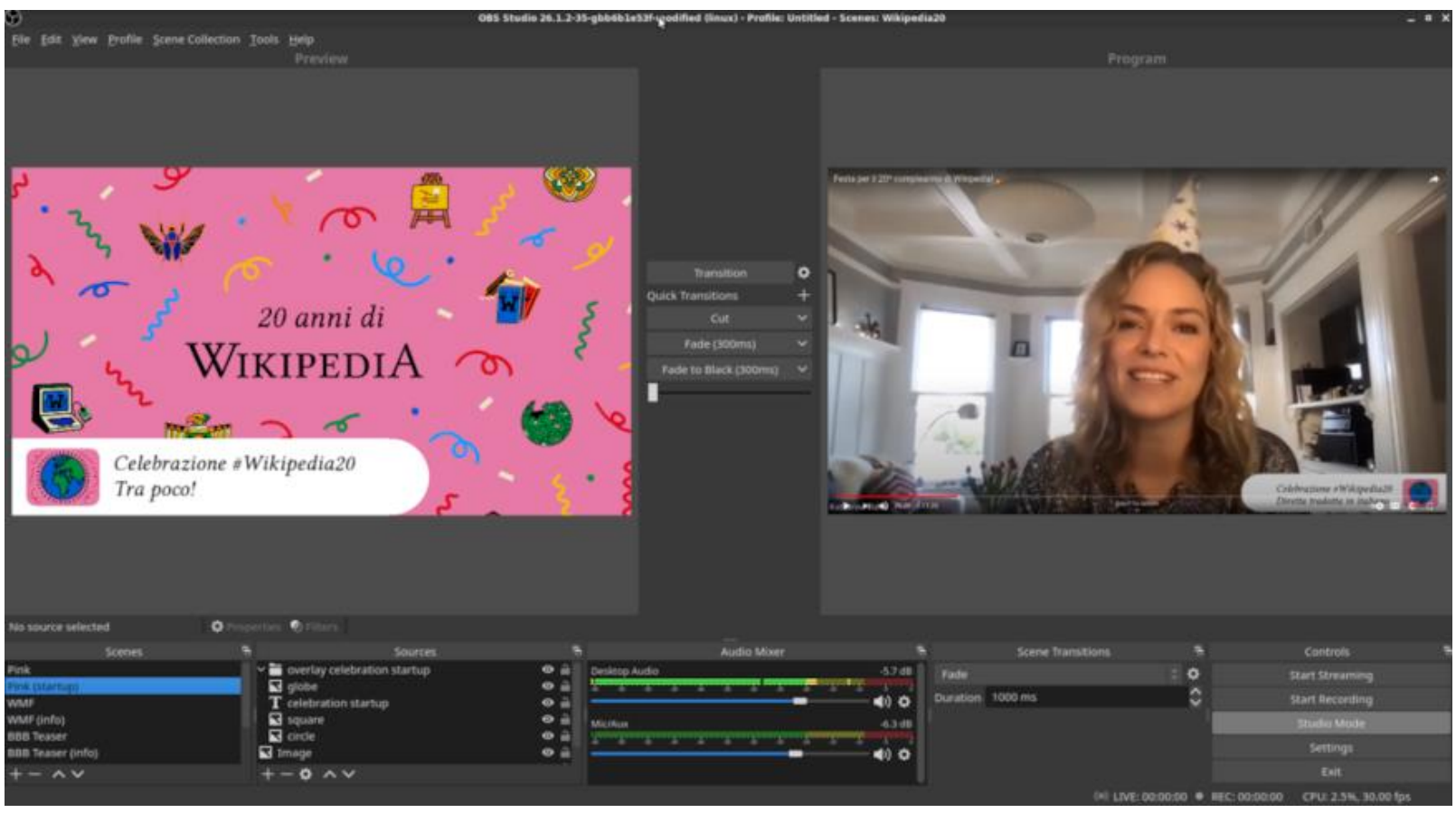

Note.https://commons.wikimedia.org/wiki/File:Open_Broadcaster_Software_serving_the_live_ translation_in_Italian_of_the_Wikipedia_20th_Birthday_Global_Celebration.png; Valerio Bozzolan, CC BY-SA 4.0, via Wikimedia Commons.

While the dramatic pretense of the videoconference was that it was a TV show, it included specific Japanese instructional content from the elementary Japanese textbook Genki: An Integrated Course in Elementary Japanese I, Unit 6 (Banno et al., 2020). The new grammar involved the -te form of Japanese verbs and three of its uses, one for making polite requests (-te

2 The recording was subsequently edited to remove overly long silent gaps and unintentional gaffs. It can be viewed at the following URL: https://drive.google.com/file/d/1GntL3410_7V- 
kudasai), one for expressing permission to do something (-te mo ii), and lastly one for denying permission (-te wa ikemasen).

\section{Interactive Theater at a Distance}

Before the Japanese lesson begins, seminar students and I casually greet and talk to online students in English and Japanese as they enter the Zoom session. No one is yet "in character." After all the online students have entered, the show begins with conventional signifiers of television, first, with a fade to black, then fade to an opening credit consisting of a logo in Japanese script over a still shot of the university, accompanied by catchy music (see Figure 2). Except for perhaps the word for "university," the name of the university in kanji (Chinese characters used to write Japanese) would most likely be beyond the reading ability of the students of Japanese. In any case, black screen, fade to credit, and music only serve the purpose of signifying that the viewer is watching Japanese TV, as opposed to a videoconference for learning Japanese.

\section{Figure 2}

Opening and Closing Credit With Still Shot and University Name and Logo

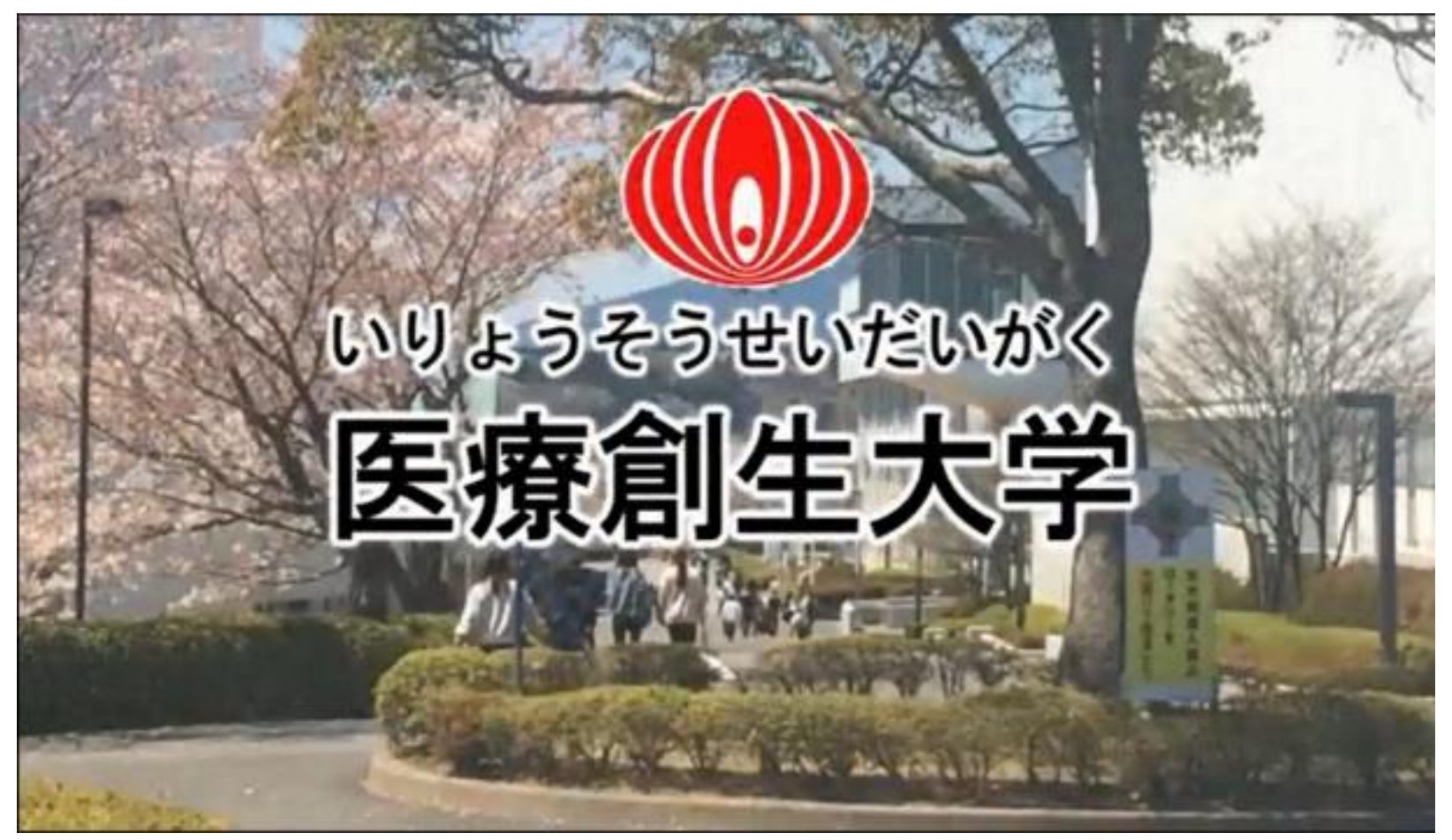


The show is staged in a university classroom, not because this is a class, even though it is, but because this is a show about a class. This distinction allows for events to occur that assist the narrative structure of the show but would constitute gaffs in an actual class. The gaffs themselves have been scripted, choreographed, and rehearsed, although actual gaffs occur as well, for example, when actors forget the choreography, or I, controlling the computer, momentarily show the wrong media element.

After the opening credit, everyone appearing on camera assumes a particular role. There are three characters: one who plays a teacher and two who play students. The first character to appear is a teacher standing behind a teaching station at the front of a classroom (see Figure 3). As he introduces himself, a superimposed lower third title graphic shows his name in Japanese, again in characters that viewers probably cannot read in the amount of screen time given. In any case, the viewers will have already known him from past interactions, the most recent one being just a few minutes prior to the black screen and credit announcing the theatrical space. The superimposed title graphic, a conventional television practice for anyone in the host position, serves to identify the character as a character.

\section{Figure 3}

\section{The "Teacher"}

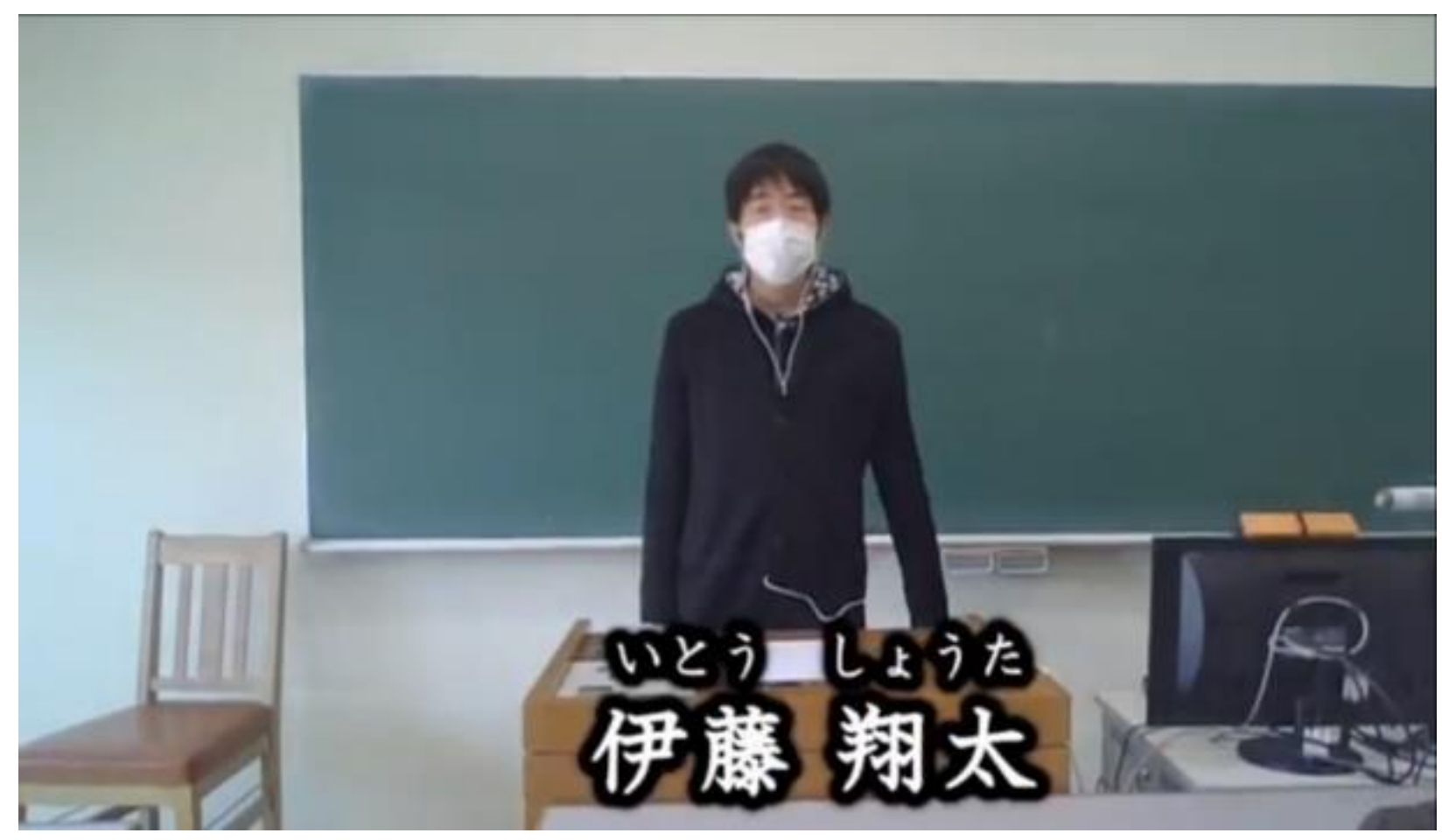


The next person to appear, seen in Figure 4, is a student who just stands at the entrance as if he is unsure if he can enter. The teacher waves him to come in, but the student still is unsure, as if he wants to explicitly hear it stated, "Come in." The teacher had just shown a graphic with the Japanese word for "classroom" and had an online student read it, then showed still images of various kinds of classrooms while repeating this word. Ostensibly, the teacher went through this to tell online students where he was - in a classroom - but the real reason was so he could use this later to tell the student at the entrance to enter the classroom. The teacher had also taught the word for "enter" in the same way, with video clips of people entering various rooms, buildings, and a bathtub. When the student appears at the classroom entrance, the teacher turns to the camera and shows how to make a polite request out of this verb, after which an online student says to the student at the entrance, "Please enter the classroom" in Japanese. Only then does the student finally enter.

\section{Figure 4}

\section{Student Standing at the Entrance to the Classroom}

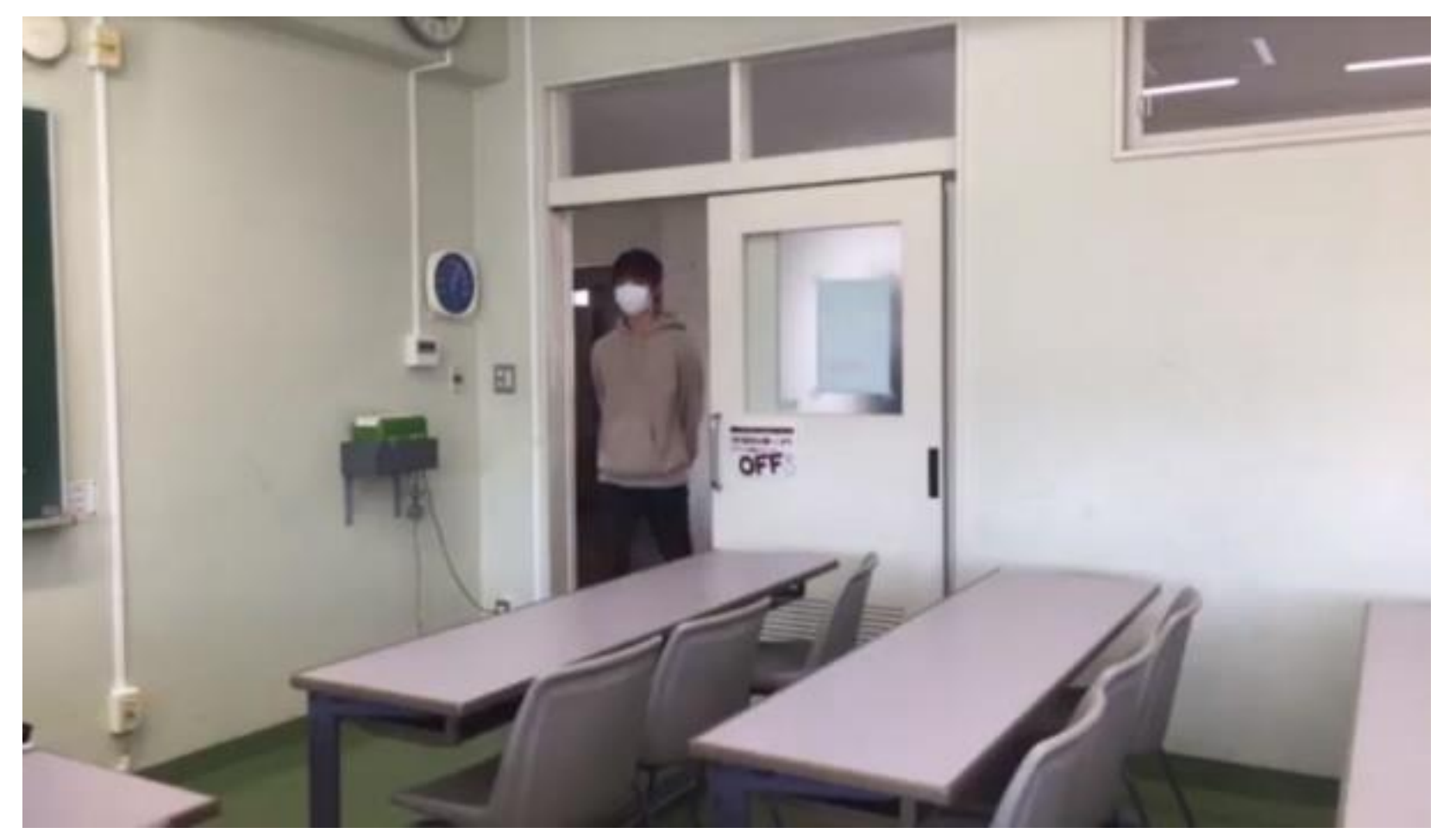


After the student enters, he goes to a chair, but for some reason he just stands by it. Similar to the setup of a joke, the whole routine with "enter" is repeated for the word for "sit," after which the student sits down, presumably to start taking the class.

Next, another student appears at the entrance and the "enter" and "sit" routines are repeated. Then the first student, pointing to the hallway outside, asks if he can go to the bathroom and the pattern is repeated with "go." The first student then gets up and walks out.

The teacher continues to be interrupted with requests when the second classroom student in Figure 5 holds his box lunch as if to ask if he can eat it. Again, the teacher turns to an online student first to elicit the Japanese for "May I eat my box lunch?" (Figure 6), only after which the second student asks properly. Instead of immediately answering the request, the teacher asks the online student what he thinks, if it is permissible to eat lunch during class in an American school. The online student says "no," then the teacher tells the classroom student "no."

\section{Figure 5}

\section{Student Asks for Permission to Eat Box Lunch}

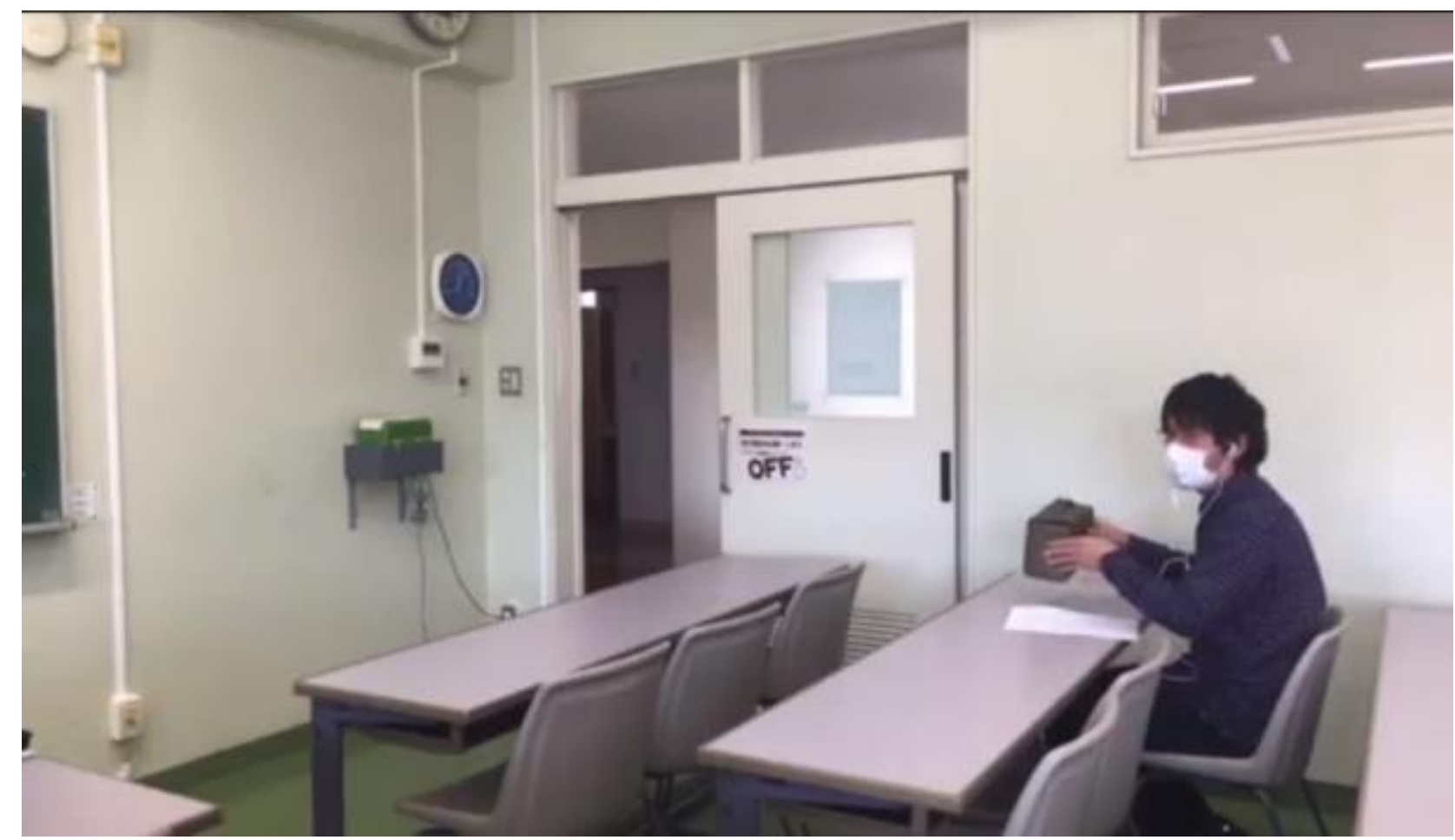




\section{Figure 6}

Using Graphics to Elicit "May I Eat My Box Lunch?”

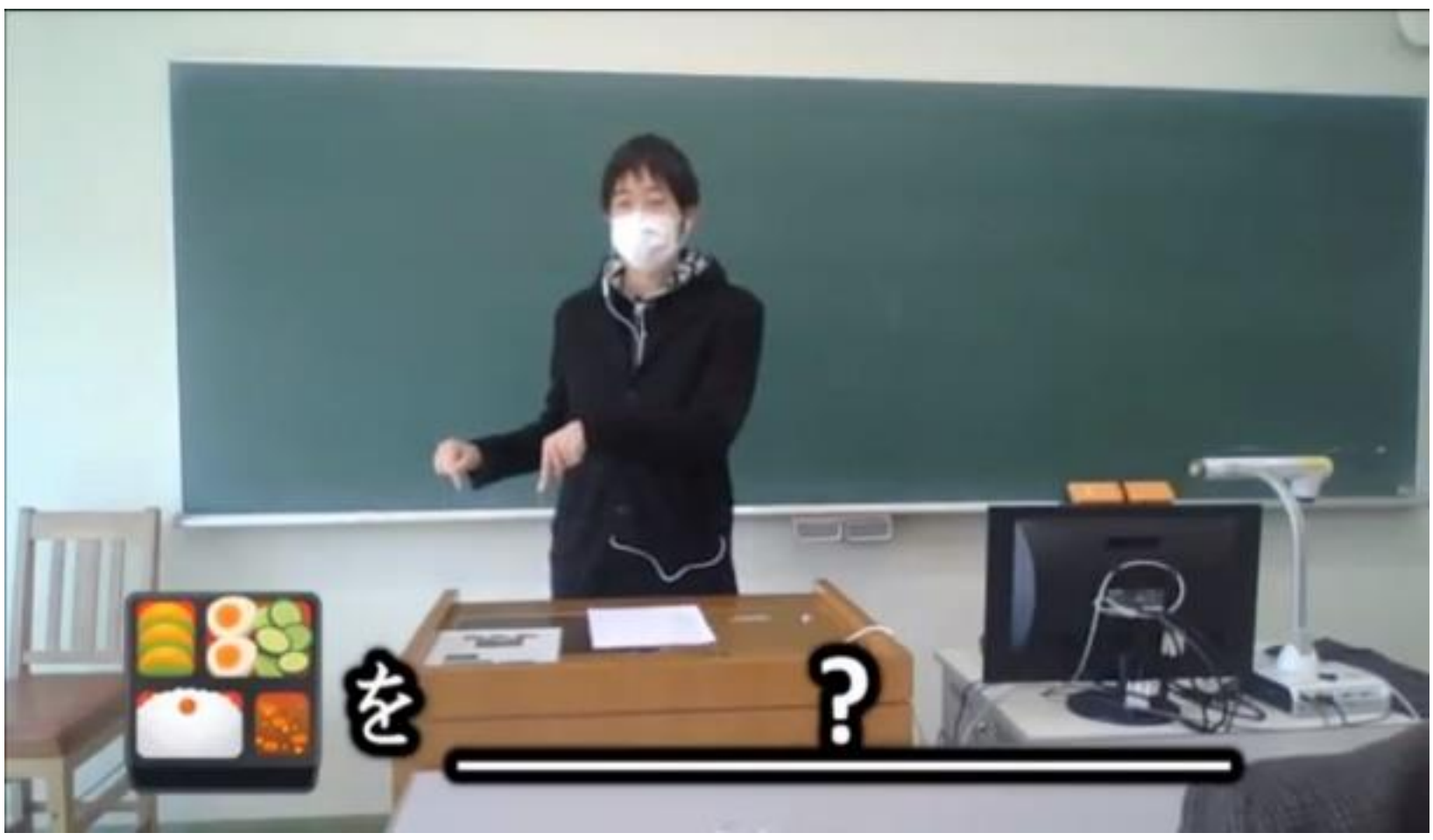

At relevant spots all through the conversation, video clips are dropped in of a student in a library who is violating all the rules by eating potato chips, drinking juice, listening to music, and singing to the music. Other students try to tell him that those actions are not allowed, but he pays no attention until a librarian approaches him on each infraction and asks the student if he thinks it is allowed. Each time, the student is forced to admit that it is not allowed and hands over the offending item to the librarian, as in Figure 7. Each time, the librarian takes the item back to her desk. 


\section{Figure 7}

\section{Librarian Reprimands Student for Drinking Juice in the Library}

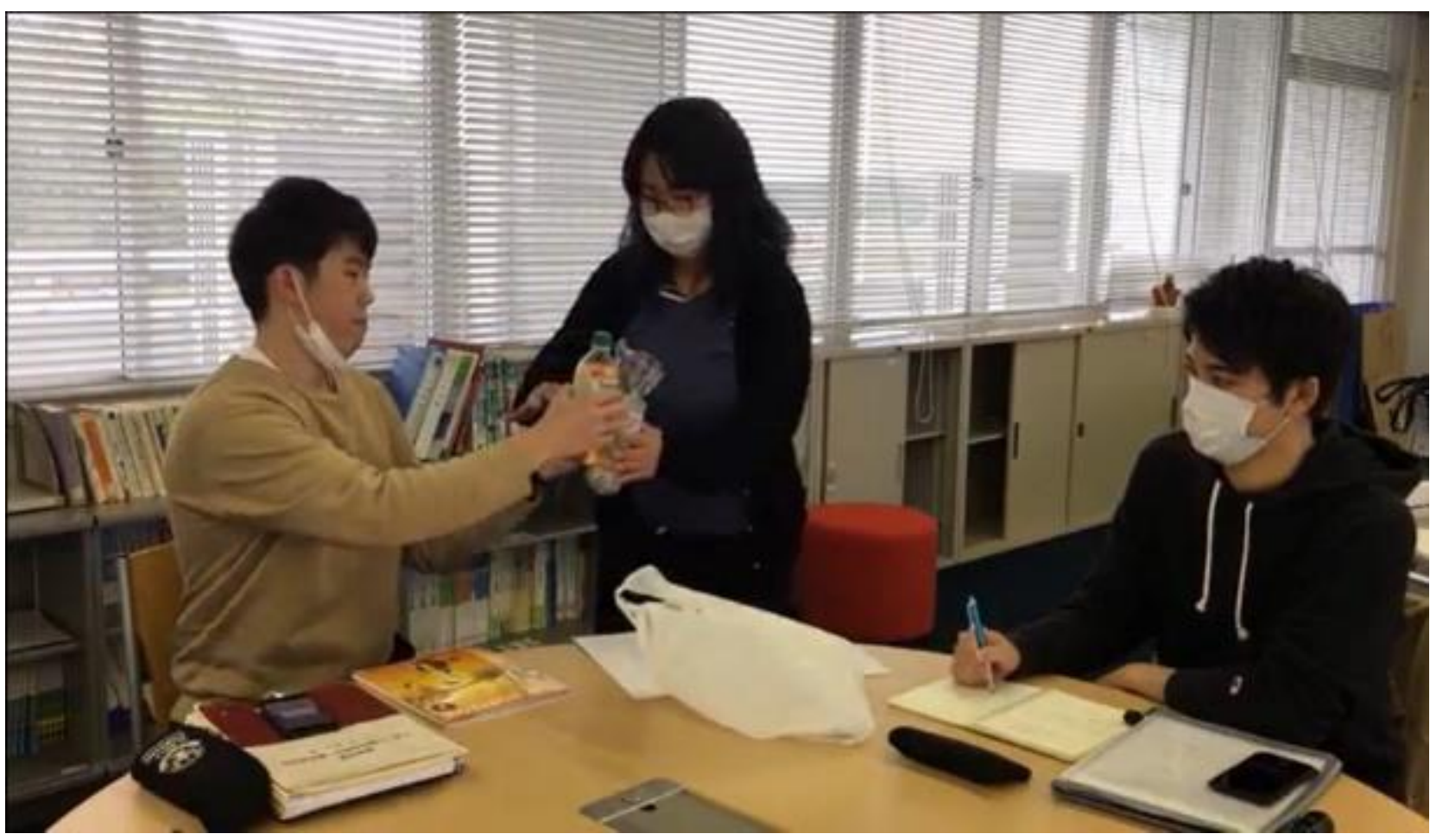

After the teacher has finished asking online students about what is and what is not permissible in the United States, the library sketch is shown in its entirety. The resolution of the sketch - the theatrical punchline - is when we see the librarian succumbing to temptation to indulge in the confiscated items. The camera then zooms out to show the librarian surrounded by the offending student and all the other students in the previous shots (Figure 8). They ask in chorus "Is it allowed to eat in the library?" "Is it allowed to drink in the library?" and so on. To each question, the librarian sheepishly says it is not allowed. The scene ends with the sad trombone "wah-wah-wah" sound understood in both American and Japanese culture as failure in a comedic context. 


\section{Figure 8}

\section{Librarian Caught Breaking the Rules}

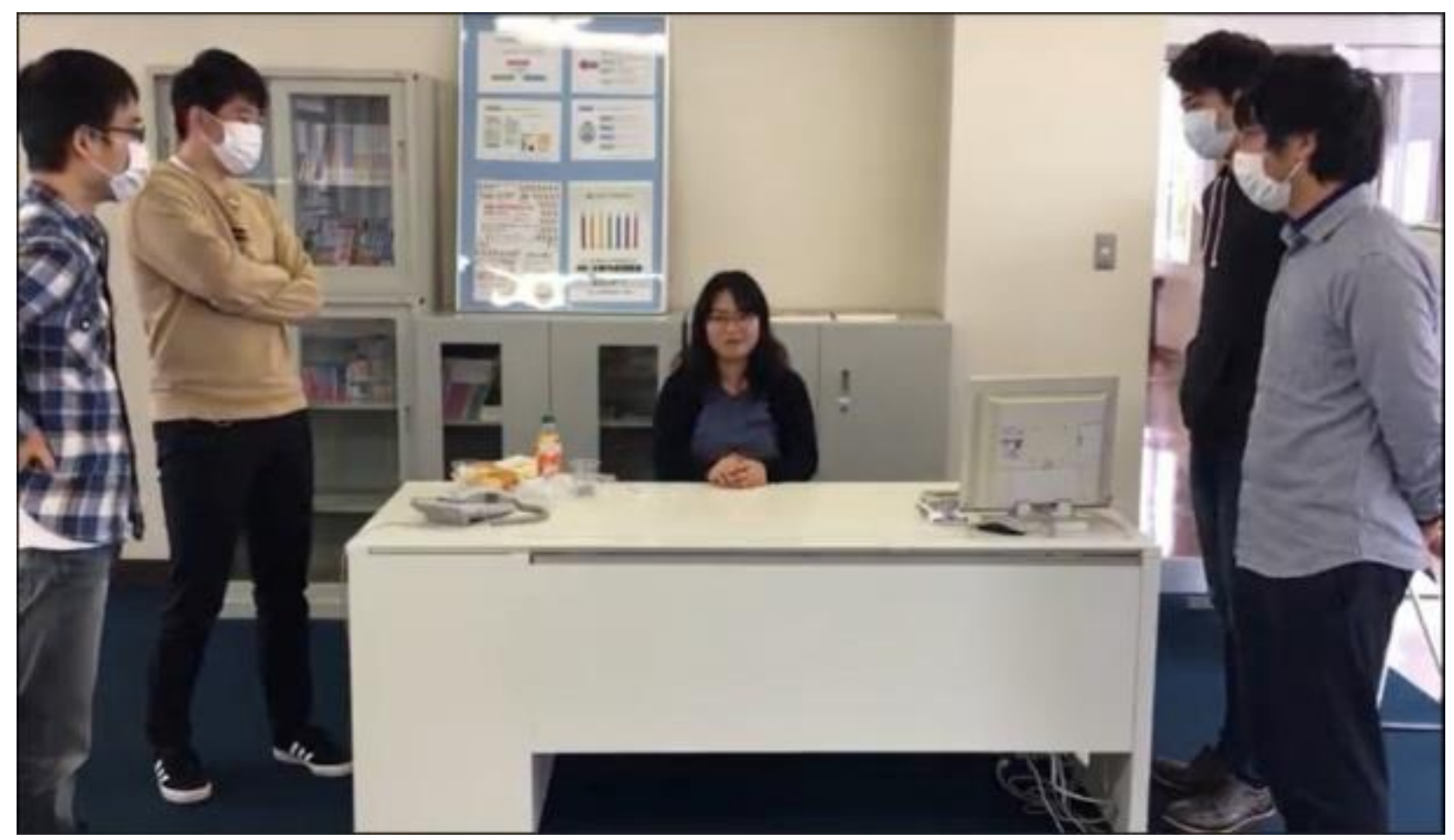

After the whole sketch is finished, we come back to the live classroom scene to find the student who went to the bathroom now talking to someone out in the hallway. The teacher goes to the classroom entrance and asks an online student if it is OK to talk to friends outside the classroom during class. The online student inevitably says "no" and tells that to the classroom student, who then agrees to come back in and sit down. After this entire series of passiveaggressive behaviors that teachers know well, everyone finally seems ready to start studying. The teacher says "OK, let's study Japanese" but just then, the bell rings indicating that the class is finished. The students quickly ask if it is OK to go to the next class. The exasperated teacher tells the students to wait and to at least say "good-bye" to the online students. As they do, the theme music starts playing and closing credits roll by. All the students, both those who were on camera and behind the camera appear to say good-bye (Figure 9). The credits again roll by too fast to be read, even the ones in English, but again, it is only a pretense that credits are serving the purpose of informing the viewer of who is responsible for the TV production and what resources were used in it. What the credits really signify is that what we have just watched was TV. 


\section{Figure 9}

\section{Rolling Closing Credits Over Students}

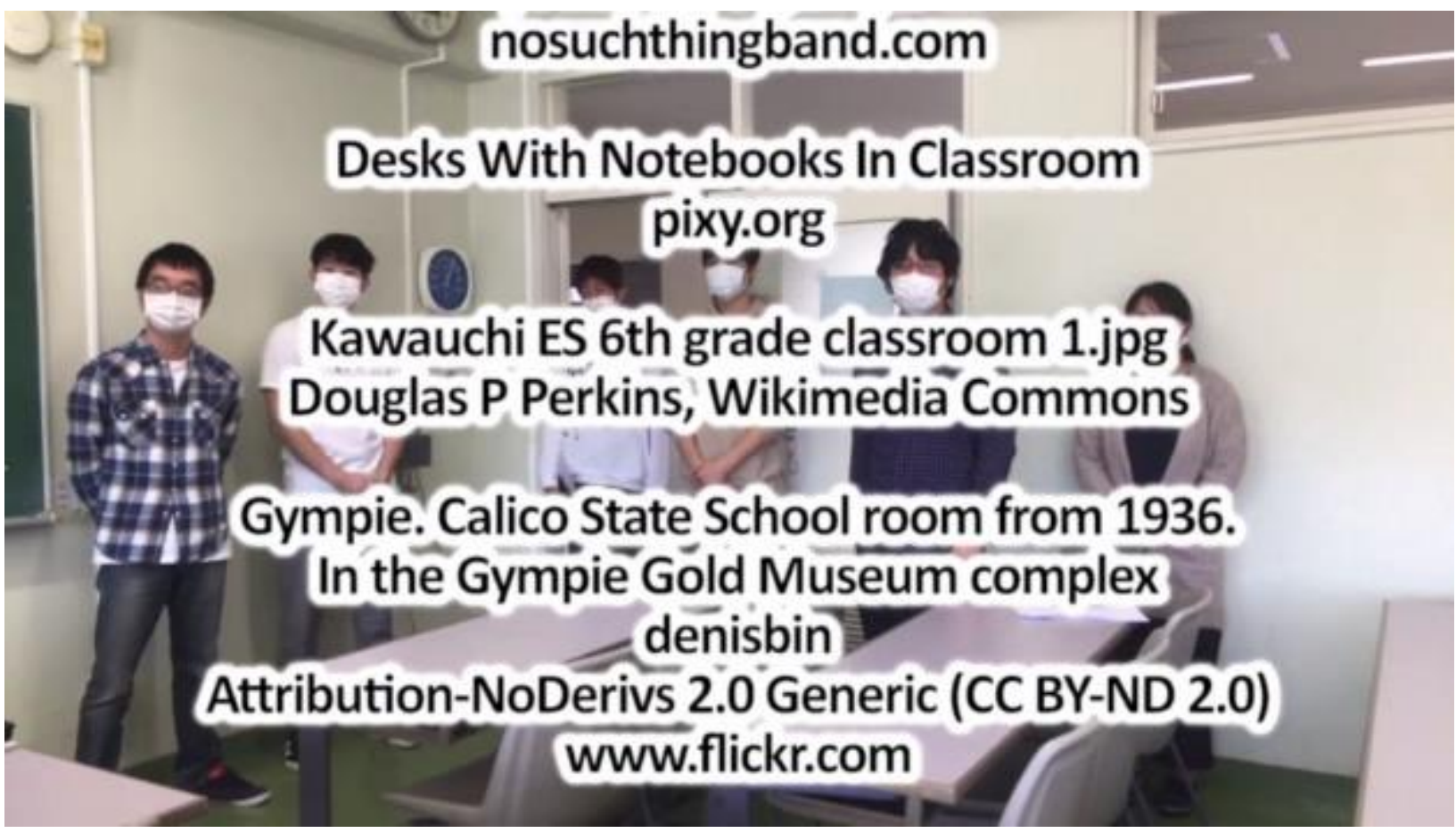

After the last credit, which was the first credit in Figure 2 at the beginning of the show, the video fades to black for a few seconds, then fades back to the classroom. The fade-to-black, like the closing curtain in theater, signifies the end of the show, a break between the world of makebelieve and the real world, between the actors acting in character and acting as "themselves." After that break, the conversation turns to English.

\section{The Learning Experience for the Participants}

During the closing credits, the online student participants were heard in the video voicing their pleasure at having participated. "It was really so amazing," one student said. "They did so well, they did sooo well," said another. "They were so fun, so sweet." The online students came from a wide range of Japanese-language abilities. Some voiced their comments in Japanese. Totemo tanoshikatta desu ("That was so fun"), one said. Wakari-yasui desu ("It's easy to understand") was another comment. Sanka sasete kurete arigatou gozaimashita ("Thank you for letting me participate"), said one student in rather advanced Japanese. However, another student from another university said "That was tough." The students' Japanese instructors were also 
online. One expressed her surprise at how novel the experience was. She also asked her students if they were nervous. Two students said they were indeed. It was as if they had experienced stage fright. As this was an interactive performance, they too were performers.

While the Japanese in the show was straight out of a Japanese textbook, the language was put into a unique context, that of an interactive show. One online student commented that, while she thought she was familiar with the language being taught and could produce it in the classroom, it seemed to "slip out the window" when she was called to use it in "real life." Other students concurred. It is ironic that they would think of a highly scripted and staged show was "real life." It could be understood that the event was not experienced as didactic, even if learning took place.

While this experience was novel for the seminar students, this being a live performance, their first reaction was to criticize themselves for their mistakes. They felt that despite having rehearsed the script several times, they had not rehearsed enough. The two most vocal of them expressed exhilaration at being part of such a performance, but the overall conclusion among the five students was that these types of performances require too much preparation. Later videoconferences were held in visually interesting locations, including a park, a reconstructed traditional Japanese farmhouse, and my own apartment. These were all rehearsed as well, but they were all in an explanatory mode; there was no storyline running through them.

\section{A Model for Foreign Language Instruction?}

For the seminar students, acting on camera was at once thrilling and scary; however, their final verdict, as well as the work involved to produce such a videoconference, would seem to point to the ultimate futility of the exercise. The show followed a script that spelled out each video clip, music clip, still image, graphic text, motion graphic, sound effect, or camera shot seen or heard at any given moment. Each element had to be created or found online with copyright clearance, then programmed into the video production software. Even after the best preparations, several technical problems and human errors arose. As the seminar instructor, I had intended to teach students how to use my laptop computer to edit video and arrange media elements into live video feeds, but that was precluded by the COVID-19 situation. 
Despite the challenges and the conclusions of the seminar students, it is worth noting that the distance learning programs I had created in the past for public television entities spent millions of dollars to do basically the same thing, albeit at a more polished level. That money covered budgets for professional television equipment and armies of production and administrative staff. More recently, especially in the days of COVID-19, many teachers, whether by choice or requirement, have been teaching on videoconferencing or other teaching platforms that include an option for live video. Much attention has rightly been devoted to the design of such programs to ensure that students are engaged in learning activities, but little to no attention goes into the video itself. Typically, the most creative options for teachers are choosing an interesting still background for their talking head. For no extra cost in equipment, teachers can add a theatrical nod to what they do on videoconferencing platforms every day. With the addition of a modest technology budget, a teacher could employ much better video and audio quality. The cost would still be incomparably less than what educational institutions were willing to spend on past distance learning productions.

Given the demands to produce such a videoconference, teachers that lack acting and media production experience are unlikely to add a demanding video project to their busy schedules. However, for teachers that do have such experience, or are interested in gaining it, videoconferencing in imitation of and in homage to television is worth consideration. Instead of foreign language teachers adding this as a project, teachers in institutions housing theater and media studies could undertake this as the focus of a unit or semester in collaboration with foreign language teachers. Moreover, if a teacher were too time-strapped to create a rich media production, but had students with strong acting skills, those skills could compensate for less media. Rather than serve as a second-best tool after teaching in person, video can be its own best tool for a new kind of rewarding experience. Used in this way, a videoconference in a foreign language presents far more possibilities than language teaching and learning alone. In an ever more technologized society with all its present potential and pitfalls, it creates new ways to be human. 


\section{References}

Banno, E., Ikeda, Y., Ohno, Y., Shinagawa, C., \& Tokashiki, K. (2020). Genki: An integrated course in elementary Japanese I (3rd ed.). Japan Times Publishing.

Bruning, R., Landis, M., Hoffman, E., \& Grosskopf, K. (1993). Perspectives on an interactive satellite-based Japanese language course. American Journal of Distance Education, 7(3), 2238. https://doi.org/10.1080/08923649309526831

Carey, J., \& Elton, M. C. J. (2010). When media are new: Understanding the dynamics of new media adoption and use. University of Michigan Press.

Masats, D., Dooly, M., \& Costa, X. (2009). Exploring the potential of language learning through video making. In L. Gómez Chova, D. Martí Belenguer, \& I. Candel Torres (Eds.), Proceedings of EDULEARN09 Conference (pp. 341-352). Valencia: IATED. https://www.researchgate.net/publication/267305809_Exploring_the_potential_of_language_le arning_through_video_making

Yi, H., \& Majima, J. (1993). The teacher-learner relationship and classroom interaction in distance learning: A case study of the Japanese language classes at an American high school. Foreign Language Annals, 26, 21-30. https://doi.org/10.1111/j.1944-9720.1993.tb01147.x

Timothy M. Cook is Professor of English at Iryo Sosei University, Japan. He holds an MAT in Teaching ESL/EFL from the School for International Training and $\mathrm{PhD}$ in Communication Studies from the University of Alabama. Among his acknowledgments are an Emmy award in the category of individual performance for his teaching Japanese on Georgia Public Broadcasting, and designation as a Master Folk Artist by the Alabama State

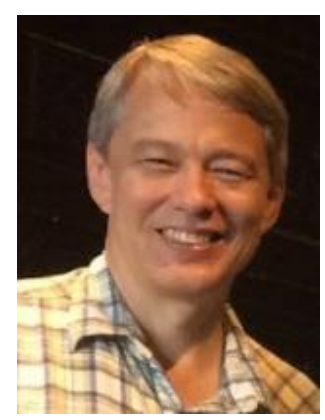
Council on the Arts for the teaching of shape-note singing.<timothy.cook@isu.ac.jp> 